\title{
FRONTIERS OF SOVIET RESETTLEMENTS: CULTURAL BORDERS AND CROSS-CULTURAL INTERACTION BETWEEN RUSSIANS AND CHUVASHES IN THE SOUTH PART OF KAMA REGION IN THE 1920-1930S
}

\author{
Alexander V. Tschernych (a) \& Mikhail S. Kamenskikh (b) \\ (a) Perm Federal Research Center of Ural Brunch of Russian Academy of Science. Perm, Russia. \\ Email: atschernych[at]yandex.ru \\ (b) Perm State National Research Polytechnic University | Perm Federal Research Center of Ural Brunch \\ of Russianacademy of Science. Perm, Russia. Email: pomidorrr[at]mail.ru
}

\begin{abstract}
The article is devoted to the analysis of ethno-social resettlement campaigns of the USSR of the second half of the 1920s. The implementation of these practices in the Volga Region led to major migrations and the formation of ethnic enclaves on the territory of Urals and Siberia. Basing on various sources and field materials, the article describes the situation in the Southern Prikamye after several thousand of the Chuvash people migrated to the places inhabited by Russian Old Believers. The sources allow to reconstruct complex processes of ethno-cultural interaction that formed new specific complexes of spiritual and material culture of the Chuvash people of Prikamye. The authors noted that the resettlement in the 1920s took place in the conditions of the destruction of the traditional life characteristics in the whole country, a change in ideological attitudes, a significant transformation of ethnocultural complexes. Under the conditions of migration, these factors contributed to a more intensive course of assimilation processes. At the same time, a significant number of Chuvash migrants encamped in one area at a distance from large settlements, as well as preservation of the rural character of the outposts contributed to the functioning of institutions for keeping the traditional way of legacy transmission.
\end{abstract}

\section{Keywords}

The Chuvash People; Russians; Resettlement; Prikamye; Migration; Population Census; Traditional Culture 


\title{
ФРОНТИРЫ СОВЕТСКИХ ПЕРЕСЕЛЕНИЙ: КУЛЬТУРНЫЕ ГРАНИЦЫ И КРОССКУЛЬТУРНОЕ ВЗАИМОДЕЙСТВИЕ РУССКИХ И ЧУВАШЕЙ В ЮЖНОМ ПРИКАМЬЕ В 1920-E - 1930-Е ГГ.
}

\author{
Черных Александр Васильевич (a), Каменских Михаил Сергеевич (b)
}

(а) Пермский федеральный исследовательский центр Уро РАН. Пермь, Россия.

Email: atschernych[at]yandex.ru

(b) Пермский национальный исследовательский политехнический университет | Пермский федеральный исследовательский центр Уро РАН. Пермь, Россия. Email: pomidorrr[at]mail.ru

\section{Аннотация}

Статья посвящена анализу этносоциальных последствий переселенческих кампаний в СССР второй половины 1920-х гг. Включение в их реализацию народов Поволжья привело к крупным миграциям и формированию этнических анклавов на территории Урала и Сибири. В статье на основании источников и полевых материалов автора представлена ситуация, сложившаяся в южном Прикамье после миграции нескольких тысяч чувашей в населенные пункты, жителями которых являлось русское старообрядческое население. Источники позволяют реконструировать сложные процессы этнокультурного взаимодействия, сформировавшие новые специфические комплексы духовной и материальной культуры чувашей Прикамья. Авторами отмечено, что переселение в 1920-е гг. проходило в условиях характерного для всей страны разрушения традиционного уклада, смены идеологических установок, значительной трансформации этнокультурных комплексов. В условиях миграции эти факторы способствовали более интенсивному протеканию процессов ассимиляции. В то же время значительная численность чувашских переселенцев, расселение одним ареалом в отдалении от крупных населенных пунктов, сохранение сельского характера расселения способствовали обеспечению функционирования институтов поддержания традиционного уклада их межпоколенческой трансляции.

\section{Ключевые слова}

чуваши; русские; переселение; Прикамье; миграция; переписи населения; традиционная культура

Это произведение доступно по лицензии Creative Commons «Attribution» («Атрибуция») 4.0 Всемирная 
Журнал Фронтирных Исследований. 2021. No 4 | ISSN: 2500-0225

Этнические меньшинства в контактных зонах | Doi: https://doi.org/10.46539/jfs.v6i4.337

\section{ВВЕДЕНИЕ}

Одной из важных составляющих внутренней экономической политики СССР второй половины 1920-х гг. стали переселенческие кампании. Проблема перенаселения центральных районов страны, с разной степенью успешности решаемая царским правительством, не перестала быть актуальной даже после голода и Гражданской войны (Платунов, 1976, с. 5). К середине 1920-х гг. советские эксперты, ответственные за переселенческую политику, оценивали избыток населения в центральных районах СССР в диапазоне от 10 до 23 млн. человек (Каменских, 2019, с. 144).

Согласно источникам, во второй половине 1920-х гг. усилился самостоятельный выезд населения из деревни в города. По данным Наркомтруда, больше всего отходников выходило из Поволжья и Украинской ССР. Так, из Средне-Волжского района в 1923/1924 гг. вышло 104,8 тыс. человек, в 1924/1925 гг. - 214,0 тыс. человек, в 1925/1926 гг. 246,4 тыс. человек (Платунов, 1976, с. 57). Из Украинской ССР за эти же годы соответственно - 148,7 тыс., 379,8 тыс. и 474,9 тыс. человек (Минц, 1929, сс. 292-293). Миграция уже началась стихийно, и отказ от участия государства в ее организации мог привести только к новым крестьянским волнениям. По этой причине советское правительство вернулось $к$ дореволюционной идее стимулирования миграции из перенаселенных районов Поволжья и Центральной России на Урал.

Новую переселенческую политику планировалось вести административным путем. Советским органам, уверенным в преимуществах плановой системы, казалось, что формирование земельных фондов и регулированная переброска населения позволят решить проблему перенаселения. Еще на совещании по организации переселенческой кампании в 1927 г. один из ее идеологов Н. Турчанинов так видел ход переселения: «Мы должны организованно проводить переселение, проводить его под общественным контролем» (РГАЭ, 1927, л. 47).

Для реализации переселения был принят Пятилетний перспективный план переселенческих мероприятий на 1928 / 1929 1932 / 1933 гг. (ГАСО, 1933, л. 14). В п. 2 плана «Общие задачи промышленной колонизации на Урале. Первоочередные районы колонизации», сообщалось о подготовке строительства новых «крупнейших» предприятий на Урале: «Все это должно вызвать большой приток рабочей силы, и, в результате существенного изменения в распределении населения, возникновение новых крупных поселений городского типа и вокруг них целых групп обслуживающих их нужд сельских пунктов» (ГАСО, 1933, л. 15). В задачи созданной для этих 
целей Уральской районной переселенческой организации входила колонизация будущих промышленных центров севера и юга Урала Нижнетагильского и Верхне-Камского округа, а также Магнитогорского района Троицкого округа. В связи с подготовкой строительства новых «крупнейших» предприятий на Урале планировалось существенно увеличить объемы лесозаготовок. На тот момент они на $75 \%$ велись привозными рабочими из лесных губерний Европейской части России общей численностью свыше 10 тыс. человек. Для обеспечения нужного количества рабочих планировалось переселить 7-8 тыс. семей и создать 150 поселков из расчета 50 дворов на поселок (ГАСО, 1933, л. 15).

Переселенческие кампании второй половины 1920-х гг. спровоцировали миграции сотен тысяч человек, изменив этнокультурный облик многих регионов. В «районах вселения» не только изменялись этнический состав и этнокультурная ситуация, но и появление новых жителей не всегда воспринималось позитивно. Нередко за счет переселенцев происходило формирование новых этнических ареалов расселения, в результате чего складывались новые районы активных межэтнических контактов. Это приводило к появлению этнических границ внутри локальных социумов.

Необходимо отметить, что, несмотря на серьезное внимание большевиков к решению национального вопроса и недопущению конфликтов на межнациональной почве, этносоциальные последствия переселений не брались в расчет и не считались частью национальной политики. Из стенограммы Всероссийского совещания работников по переселенческому делу 1927 года видно, что данный вопрос практически не обсуждался. Лишь однажды за три дня работы его коснулся представитель ЦИК И. Сабиров:

«Я хочу присоединить к этим трудностям еще один момент, который никем пока еще не был затронут. Это, товарищи, состав наших поселенцев, который у нас различен по национальному составу. У нас в РСФСР имеется много миллионов мелких национальностей, живущих в тех губерниях, которые дают переселенческий контингент. Каким образом поставить работу среди нацменьшинств, эту работу вообще вести очень трудно, даже там, где население сидит компактно» (РГАЭ, 1927, л. 277).

Однако эта реплика осталась без обсуждения и не была услышана. Другими словами, отдельных мер, направленных на социальнокультурную адаптацию переселенцев, не предпринималось. Таким образом, изучение взаимодействия новых переселенцев со старожильческим населением в рамках советских переселенческих кампаний 
представляется актуальным. Этапы и ход подготовки и реализации переселенческих кампаний был досконально изучен еще современниками тех событий (Минц, 1929; Баранов, 1929; Большаков, 1923, Лидкин, 1931; Лубны-Герцык, 1923).

Отдельные аспекты миграционных процессов этого периода в этническом контексте получили освещение в исследованиях пермских историков и этнологов (Федоров, 1928; Черных \& Каменских, 2014; Каменских, 2018). Авторами изучены документы по истории переселения, отложившиеся в фондах Пермского государственного архива социально-политической истории (ПермГАСПИ), Государственного архива Свердловской области (ГАСО) и Государственного республиканского архива Удмуртской Республики. Важным источником, пока не оцененным в должной мере исследователями, является стенограмма совещания по организации переселенческой кампании в 1927 г. из фондов Российского государственного архива экономики (РГАЭ). Источник не только содержит базовые документы переселенческой кампании, но и отражает дискуссии участвующих сторон в ходе обсуждения и принятия решений. Кроме этого, авторами собран ряд документальных свидетельств, семейных преданий и полевых материалов в рамках экспедиций 1996, 2000, 2001, 2002 в Куединском, Чайковском и Чернушинском районах Пермского края (ПМА полевые материалы автора, АНКЦЧПК - Архив Национально-культурного центра чувашей Пермского края).

Одним из активных участников переселенческого движения второй половины 1920-х гг. стали территории Поволжья, страдавшие от последствий голода и отсутствия лесных ресурсов. Наиболее интенсивным было переселенческое движение чувашей. По данным историков, специализирующихся на этнической истории чувашей, до $80 \%$ населения Чувашии к концу Гражданской войны остались без средств к существованию, а более половины дворов осталось без лошадей и коров, был уничтожен почти весь мелкий скот. К февралю 1922 г. число голодающих составило около 595 тыс. чел. из 850 тыс. населения автономии, а умерших от голода - более 12 тыс. человек (История Чувашии, 2001, с. 162). Чтобы решить вопрос с голодом и аграрным перенаселением, власти автономии пошли на плановое переселение части крестьян за пределы автономии. По плану Наркомата земледелия Чувашской АССР в 1926 года, около 350 тыс. человек должны были быть переселены за территорию Чувашии. Свою роль сыграла сильная засуха, случившаяся на территории Чувашии в 1927 г. (История Чувашии, 2001, с. 162). Таким образом, осуществилась массовая миграция чувашей за пределы мест традиционного прожи- 
вания. Большая часть мигрантов этого периода переселялась в районы Сибири и Зауралья. Д.Г. Коровушкин назвал миграционную волну 1921-1929 гг. «самым значительным периодом переселения чувашей» (Коровушкин, 2009, с. 68).

Миграции второй половины 1920-х гг. из районов традиционного расселения чувашей затронули и южные территории Сарапульского округа Уральской области. Сюда, на земли современных Чернушинского, Чайковского, Куединского, Еловского и Октябрьского районов в конце 1920-х гг. переселилось несколько тысяч чувашей. Они заселяли деревни со старожильческим русским населением, среди которых, наряду с православными, проживали представители разных старообрядческих согласий (Черных \& Каменских, 2014, сс. 37-38).

В рамках данной статьи планируется проанализировать, как происходило переселение, осуществлялось взаимодействие русского населения южного Прикамья с переселенцами чувашами в конце 1920 - начале 1930-х гг., какие, в связи с этим, произошли трансформации комплексов традиционной этнической материальной и духовной культуры.

\section{ПЕРЕСЕЛЕНИЕ ЧУВАШЕЙ В ПРИКАМЬЕ}

Массовая миграция чувашей в Прикамье началась в 1928 г., причем по ходу переселенческой кампании был зафиксирован рост самостоятельных переселенцев из Чувашской АССР (ЧАССР) на территории Сарапульского округа Уральской области, где не было земельного фонда. 21 мая 1929 года Уралоблисполком проинформировал Наркомзем РСФСР, что фиксируется резкое увеличение «случаев самовольного переселения из Чувашской АССР (ЧАССР) в Уральскую область, причем движение это идет не только в округа, открытые для переселения, но и в округа, совершенно не имеющие свободных земель, в частности в Сарапульский округ» (ГАСО, 1933, л. 41). В связи с этим Наркомзем РСФСР предложил Наркомзему ЧАССР «принять самые решительные меры к прекращению дальнейших выдач переселенческих документов в районы, закрытые для планового переселения, так как это влечет за собой самые тяжёлые последствия» (ГАСО, 1933, л. 12). Позже Наркомзем ЧАССР сообщил в Сарапульский окрисполком, что переселение в закрытые местности «никогда не поощрялось и никогда не будет поощряться... но переселение в Сарапульский округ, вызванное общеэкономическими условиями, не может быть прекращено в кратчайший срок» (ГАСО, 1933, л. 42). В целом у местных органов власти не было механизмов, чтобы остановить стихийно начавшуюся миграцию. За год с небольшим тысячи 
чувашей переселились и обосновались в русских деревнях и сёлах Сарапульского округа.

К моменту переселения чувашей изучаемая территория была моноэтничной, все названные села и деревни относились к населенным пунктам русского старожильческого населения. Специфиикой этого региона Прикамья был сложный конфессиональный состав русских - они были представлены как православным населением, сторонниками официальной церкви, так и многочисленными старообрядческими согласиями, что также нашло отражение на специфике этнокультурных процессов и особенностях русско-чувашского взаимодействия (Черных, 2001). Начало коллективизации в этом районе вызвало добровольные и принудительные миграции русских из сел и деревень в Сибирь. В добровольных миграциях принимало участие в основном старообрядческое население, не принявшее начавшейся коллективизации. Поэтому чуваши, как правило, не строили новых домов, а приобретали освободившийся жилой фонд. В Большеусинском районе Сарапульского округа Уральской области, например, чуваши в конце 1920-х гг. подселились в старые русские сёла Большие Кусты, Большая Уса, Пантелеевка и русские деревни - Дубленёвка, Коровино, Батманы, Дойная, Верх-Дойная, Малые Кусты, Кирилловка, Бормист и другие. В соседнем Еловском районе они обосновываются в русских деревнях Тойкино, Бараново, Плишкари, Мельничная, Большая Талица, Большие Коптелы.

В источниках сохранилось немало упоминаний о том, каким образом чуваши приобретали новые жилища: «Несколько граждан д. Чиганды продали чувашам строения и приняли членами в своё земельное общество» (ЦГА УР, 1929, л. 122); Н.Ф. Шоркин в д. Батманы Усинского района «прибыл из ЧАССР в 1928 г. Хозяйство купил в 1928 г. за 2000 рублей...» (ПермГАСПИ, 1937а, л. 9); П. Я. Яковлев в деревню Коровино Усинского района «приехал в 1928 г., купил хозяйство середняцкое» (ПермГАСПИ, 1937b, Л. 4.); Н.К. Частоколов в деревню Дойную Усинского района «прибыл... в 1929 г., где купил хозяйство середняцкое» (ПермГАСПИ, 1937с, л. 171). Нередко усадьбы приобретались вскладчину двумя или несколькими семьями, и лишь затем сообща возводились новые дома и хозяйственные службы, и хозяйства делились. Согласно документам, хутор Окулов, выделенный из деревни Кусты в 1928 г., был «запродан пяти гражданам Чувашской АССР с уплатой последними за постройки и инвентарь 3500 рублей» (ЦГА УР, 1929, л. 129).

Таким образом, особенностью переселения чувашей в Прикамье в этот период было их вселение в уже существующие русские насе- 
ленные пункты. Неизвестно, как принималось решение о возможности принятия чувашского населения (или в этом случае действовали лишь экономические факторы), однако полевые материалы показывают, что далеко не во всех населенных пунктах, даже находящихся рядом друг с другом, в этот период селились чуваши. Так, деревни Большие Кусты и Малые Кусты приняли переселенцев, а соседняя деревня Кашка - нет, не приняли новых жителей и в селе Ошья, хотя в деревне Верхняя Ошья чуваши обосновались (ПМА, 2001-2002, д. Ошья, В. Ошья). Скорее всего, в этом случае решение принималось на сельском сходе, возможно, не без вмешательства органов исполнительной власти, что частично зависело от обеспеченности земельными наделами в том или ином населённом пункте. В деревне Чиганда, например, чувашам было продано несколько усадеб, и они были включены в земельное общество. Однако органы исполнительной власти Усинского райисполкома указывали на недопустимость доприселения в Чигандинское земельное общество по причине слабой обеспеченности крестьян деревни земельными наделами, отмечая, что большая их часть имеет незначительные земельные угодья и занимается кустарными промыслами (ГРАУР, 1937, л. 129).

В итоге такого варианта расселения сложились смешанные русско-чувашские поселения. Соотношение населения было разным, варьировалось как в разных населённых пунктах, так и в разные исторические периоды. В целом ряде русско-чувашских населённых пунктов чуваши стали преобладающим населением, что зафиксировано и похозяйственными книгами сельских администраций. Чуваши стали основным населением деревень Верх-Дойная, Дойная, Пруды, Абрамовка, Батманы, Коровино, Дубленёвка (ПМА, 2001-2002). В значительной части деревень, где обосновались чуваши в 1920-е гг., соотношение русского и чувашского населения было примерно равным. На периферии основного ареала расселения чуваши были отмечены во многих поселениях, однако проживали лишь отдельными семьями. В конце 1920-х - начале 1930-х гг. чувашами было основано несколько выселков в Усинском районе, где они составляли основное население выселок Салам, основанный выходцами из деревни Верх-Дойная, выселок Вурмеры, выселок Чёрный ключ. Выселки как форма небольшого нового дочернего поселения от деревни или села распространённый тип поселений в юго-западных районах Прикамья в 1920-х-начале 1930-х гг. Выселки были небольшими, включали чуть больше десятка домов: 
«Деревня была чисто чувашская, Салам, Шалам, Шаламово, по-разному кто и называл. Это чувашская деревня. Одни чуваши были. Было двенадцать домов, так из двенадцати потом в одном не жили, одиннадцать домов, сколь мы жили. Выехали мы из Верх-Дойной» (ПМА, 2001-2002, д. Дойная).

Названные выселки были единственными моноэтничными поселениями чувашей, возникшими в ходе миграционной волны 1920-х гг.

К началу 1930-х гг. в ЧАССР программа переселения была свёрнута. По мнению чувашских историков, основной причиной стало нежелание чувашских крестьян покидать родные места (История Чувашии, 2001, с. 162). Однако и в дальнейшем, в середине 1930-х - 1940-х гг., после завершения массового переселения, отдельные семьи чувашей переезжали в Прикамье, как правило, используя родственные связи и подселяясь в те деревни, где уже обосновались родные или знакомые.

Результаты миграции чувашей в Прикамье в конце 1920-начале 1930-х гг. видны по итогам переписей населения. Численность чувашей Прикамья в 1939 г. составляла 8821, что в 12 раз больше, чем в 1926 г. (Всесоюзная перепись 1939, 2002, с. 132). При этом доля говорящих на чувашском языке в общем количестве чувашей составила 86,6\% (Всесоюзная перепись 1939, 2002, с. 133).

Таким образом, переселенческая кампания создала на юге Прикамья крупный ареал расселения чувашей в русском окружении в несколько тысяч человек. При этом, так как эти районы не входили в число районов для переселения и миграции осуществлялись стихийно, местные власти были не готовы к работе с переселенцами, а местное население достаточно настороженно отнеслось к новым жителям.

\section{НАЦИОНАЛЬНАЯ ПОЛИТИКА И ВЗАИМОДЕЙСТВИЕ С МЕСТНЫМ НАСЕЛЕНИЕМ}

Как свидетельствуют источники и материалы полевых исследований, отношение местного населения, русских староверов, к прибывающим было в основном негативным. Среди материалов Архива национально-культурного центра чувашей Пермского края сохранились воспоминания семьи Яковлевых о первых днях жизни на новом месте. Из воспоминаний Анны Назаровны и Григория Яковлевича Назаровых: 
«В 1927 г. в Чувашии началась засуха. В поисках лучшей жизни с 5 детьми пытались прижиться в разных местах. Многое пришлось пережить - терпели унижения, оскорбления, утраты (похоронили двух детей и мать старушку). В том, что прижились в Дойной, немалую роль сыграл случай. В Большой Усе староста нас не принял, направил дальше, но при этом дал подвыпившего извозчика. Шел холодный осенний дождь. Прижавшись друг к другу, задремали. Очнулись в какой-то деревне, извозчик уехал. Попросились в первый дом, где жил Фрол Гусев. Хозяин, не обронив ни слова, пустил в сени. Утром, узнав о том, что мы чуваши, хотел выгнать, но то ли жалость, то ли интерес заставили его оставить нас у себя... Жители долго нас чурались, с опаской и недовериям смотрели вслед. Мы с большим трудом привыкли к староверским обычаям: отдыхать во время перерыва на обед приходилось вдали от других - близко не подпускали, разговор с другими заводить не подлежало. А самое обидное было то, что не разрешали брать воду из родника, объясняя тем, что «грязные» (Каменских \& Черных, с. 36).

Чувашам не разрешалось брать воду из родника, им не продавали скотину, детям не разрешали играть вместе с местными русскими. В дер. Тойкино Еловского района в 1928 г. приехало на жительство 30 семей чувашей. После того, как они обзавелись хозяйством и получили право на земельное пользование, «группа местных кулаков, пользуясь забитостью чувашей, их темнотой, установила плату за землю и усадьбу в 10 рублей, и темные чуваши платили» (Красное Прикамье, 1918). «Воду пили из отдельных кружек, на сенокосе во время перерывов отдыхали в стороне, близко их не подпускали. Разговор с другими заводить не надлежало», - говорится в воспоминаниях семьи Яковлевых (АНКЦЧПК, 2001, письма семьи Яковлевых).

Традиционный чувашский костюм заметно отличался от местного русского традиционного костюма, что вызывало удивление старожилов и их особое внимание к «чувашской моде»: «Мама рассказывала, она свой выходной наряд одела - русские подходили, рассматривали. Удивлялись. А у них другая одежда была - сарафаны кашемировые...» (ПМА, 2001-2002, с. Пантелеевка). Стремление вписаться в местный социум часто являлось причиной отказа от традиционного костюма: «Чуваши, когда сюда приехали, русские выбегали смотреть, кто такие чуваши, они же их не знали раньше. А мама в национальном костюме была. А потом папа сказал маме: “Ты больше его не надевай!” (ПМА, 2001-2002, с. Пантелеевка).

Появление этнического анклава чувашей на юге Прикамья сформировало новые социальные институты трансляции этнической культуры. Национальная политика того периода, как правило, была 


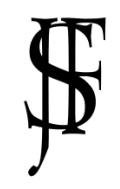

Журнал Фронтирных Исследований. 2021. No 4 | ISSN: 2500-0225

Этнические меньшинства в контактных зонах | Doi: https://doi.org/10.46539/jfs.v6i4.337

нацелена на поддержку локальных моноэтнических территориальных сообществ без учета сложного этнического состава, сложившегося в данном районе (ВКП(б), 1927; Каменских, 2019, сс. 132-140). Логика национальной политики того периода приводила к тому, что в одной деревне могли строиться школы или культурные учреждения отдельно для русских и чувашей (Черных \& Каменских, 2014, с. 38). В селе Пантелеевка Усинского района в 1930 г. была построена новая школа колхозной молодёжи (ШКМ) для чувашских детей. Начальные чувашские школы были открыты в деревнях Коровино, Чиганда, селе Дубленёвка Усинского района. Остро ощущалась проблема педагогов для чувашских школ, в которых преподавание велось как на русском, так и на родном языке (АНКЦЧПК, 2001, Письма семьи Яковлевых). С целью подготовки педагогов для чувашских школ в Пантелеевке были организованы специальные курсы (Чепкасов, 2010, c. 34).

В некоторых деревнях Усинского района параллельно были созданы русские и чувашские колхозы, как например, чувашские колхозы «Канаш» и «Чуваш» Большекустовского МТС Пантелеевского сельсовета Куединского района, занимавшиеся изготовлением мочала и ткачеством кулей. Промколхоз «Чуваш» объединял 173 хозяйства чувашей, живших на данной территории с конца 1920-х гг.

Искусственные культурные границы приводили и к межэтническому противостоянию. В ноябре 1934 года группа колхозниц «Чуваша» написала коллективное письмо в редакцию газеты «Колхозный путь». В письме колхозницы писали, что их заставляют дополнительно работать на выполнение плана колхоза «Вперед». Председатель колхоза Юрганов заставлял чувашек работать, угрожая револьвером. Пока они работали на колхозном поле, «русские женщины в своих огородах копали картошку», и что «делается это в связи с ненавистью к национальности чувашей со стороны колхоза «Вперед». (ГАСО, 1934, л. 11).

Инцидент разбирался начальником отдела нацмен райисполкома Кугушевым. В источниках сохранились показания некоторых колхозников. Из показаний Анастасии Чугуновой:

Колхозники колхоза «Вперед», видя, что нас перепуганных пригнали к ним работать, стали над нами же смеяться, говоря, что с вами чувашами так и надо поступать. Насмешки со стороны русских были и до этого, мы идем к ним работать (помогать), а они над нами смеются (ГАСО, 1934, л. 11). 
Другой колхозник Никифор Вязанов так описал сложившуюся в районе ситуацию:

В 1930-31 гг. в колхозе «Вперед» чуваш было 40-50 хозяйств, русские нас чуваш стали притеснять и над нами смеяться, в результате чего все чуваши из этого колхоза вышли и вступили в колхоз «Чуваш»... когда возникла идея принудительно две бригады влить в колхоз «Вперед», все колхозники чуваши тут же заявили т. Егорову (помощник начальника политотдела Большекустовского МТC), что «что угодно с нами делайте, мы в колхоз «Вперед» не пойдем. Уедем лучше обратно в Чувашскую АССР». Колхозники колхоза «Вперед» относятся к нам нехорошо и над чувашами смеются (ГАСО, 1934, л. 11).

Таким образом, все факты, изложенные в статье газеты «Колхозный путь», подтвердились. В итоговом протоколе отмечено, что притеснение чувашей проходило при молчаливом согласии руководства районной партийной организации:

\begin{abstract}
При проведении с/x работ руководителями районных организаций и работниками МТС систематически применялась посылка буксирных из передовых колхозов в отстающие колхозы. Так колхоз «Чуваш» из-за посылки буксира не выполнил производственную программу по промыслу на 4 квартал... После попыток Егорова насильственно передать бригады чуваш в другие русские колхозы они почти полностью не работали 2 недели, а собирались уехать в Чувашскую АССР (ГАСО, 1934, л. 7).
\end{abstract}

По итогам разбирательств председатель районной партийной организации Куединского района Юрганов был привлечен к партийной ответственности, а его дело передано в областную комиссию партийного контроля, поскольку при высылке чувашей «Юрганов применял оружие», а «бригадиру Борисову за хорошую работу обещал пулю в лоб» (ГАСО, 1934, л. 6).

Появление компактных поселений чувашей в местах традиционного расселения русских, отсутствие работы, имевшей целью интеграцию и поддержку сохранения языка и культуры чувашей, привели к формированию искусственных культурных границ в данной местности. Наличие границ, выливавшееся в том числе в межэтническое противостояние, фиксируется как источниками, так и материалами полевых исследований.

\title{
РУССКО-ЧУВАШСКИЕ ЭТНОКУЛЬТУРНЫЕ КОНТАКТЫ
}

Несколько десятилетий компактного проживания русских и чувашей на юге Прикамья сформировали особые формы развития 


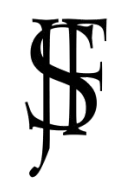

Журнал Фронтирных Исследований. 2021. No 4 | ISSN: 2500-0225

Этнические меньшинства в контактных зонах | Doi: https://doi.org/10.46539/jfs.v6i4.337

этнокультурных комплексов. Полевые исследования 2001-2002 г. позволили зафиксировать трансформацию отдельных элементов жизненного уклада чувашей после миграции. Для домашнего ткачества они, например, использовали ткацкие станы, привезённые при переселении или изготовленные по традиции, и активно пользовались русскими кроснами местных мастеров. Независимо от модели станка сохранилась технология традиционного ткачества: нити основы ткани оставляли заплетённой в косу, которую закрепляли в задней части стана (в отличие от русских, которые навивали основу на вал в задней части ткацкого стана). В основном ткали белый холст, цветную пестрядь, полусукно для изготовления одежды, полотенец и половиков. Древние приёмы чувашской вышивки не получили широкого развития в Пермском Прикамье. Как правило, местные мастерицы для орнаментации предметов одежды, бытовых тканей пользовались такими, более поздними, приёмами вышивки, как гладь, вышивка крестом. Именно в этих техниках выполнено большинство изделий (рубахи, фартуки, полотенца), изготовленных уже в Пермском крае и изученных в ходе полевых исследований (Полевые материалы автора).

Проживание в смешанных русско-чувашских деревнях чаще всего приводило к тому, что мастера-специалисты обслуживали все хозяйства. Среди кузнецов, обеспечивавших нужны крестьянских хозяйств в скобяных изделиях, ковавших и чинивших железную утварь, были как русские, так и чуваши. Их услугами пользовались все жители деревни, независимо от этнической принадлежности. Пимокатный и кулеткацкий промыслы также развивались в русско-чувашских деревнях у обоих народов. Изготовление валяной обуви, как и продукция пимокатов, и сегодня продолжают сохраняться у чувашей Пермского Прикамья, тогда как изготовление кулей из липы, освоенное чувашами в Прикамье, уже в середине XX века перестало развиваться в связи с отсутствием запроса в экономике.

Усадьба и жилище пермских чувашей не приобрели существенных особенностей, характеризующих региональную группу, поскольку переселявшиеся чуваши покупали и занимали дома русского населения, мигрировавшего в этот период в Сибирь и в города. Кроме того, начался процесс раскулачивания, поэтому в деревнях имелся незаселённый жилой фонд. Освоение сельских районов чувашами происходило в период начала коллективизации, активных трансформаций традиционной культуры, восприятия универсальных городских черт. В условиях коллективного хозяйства не было необходимости в усадебных постройках, связанных с сельскохозяйственным производством. В интерьере жилища в традиционную 
обстановку и убранство также именно в этот период активно внедряются городские формы. Для усадебного комплекса чувашей Пермского Прикамья, как и для отдельных построек (жилища, хлевов и др.), характерно активное взаимодействие местной русской традиции и традиций, перенесённых при переселении.

Между тем в ходе экспедиционной работы в домах отмечены характерные для жилища чувашей нары, являвшиеся чертой традиционного для этого народа интерьера (Гузенкова \& Иванов, с. 405). Внутренний уклад русского жилища часто воспринимался чувашами. В ходе полевых исследований информаторы указывали на преемственность отдельных элементов от местного населения: «В Чувашии у нас не было полатей, а здесь у всех полати были, у русских всё полати были. А потом уже строили, глядя на русских» (д. Коровино Куединского района). Характеризуя убранство жилища в Пермском Прикамье, отмечают его простоту, незначительное число элементов мебели: «Стол стоял, а кругом лавки, полатья были здесь» (с. Большие Кусты Куединского района). Распространённым был обычай украшать интерьер жилища к празднику ткаными и вышитыми полотенцами. Их размещали в красном углу у божницы, развешивали в простенки между окон.

О формах бытования традиционного костюма в Пермском Прикамье достаточно подробно и наглядно рассуждают наши информаторы: «Одежду больше в магазине покупали. Хранили, конечно, некоторую одежду чувашскую, одевали на праздники, на свадьбу...» (ПМА, 2001-2002, д. Коровино); «Родители с собой привезли национальную одежду, мама иногда её надевала здесь, но после войны уже и не носила...» (ПМА, 2001-2002, д. Малые Кусты); «Здесь уже по-чувашски мало носили, одежду уже по-русски носили. А после войны совсем по-русски стали ходить» (ПМА, 2001-2002, с. Пантелеевка).

Свадебный обрядовый комплекс пермских чувашей оказался наименее сохранным. Полевые исследования зафиксировали лишь фрагментарный и разрозненный материал по традиционным свадебным обрядам, в то время как другие комплексы обрядности представлены более полно. Частыми на вопрос о традиционной чувашской свадьбе были ответы: «Я даже не видала никогда чувашской свадьбы» (ПМА, 2001-2002, д. Большие кусты); «Здесь всегда делали по русскому обычаю» (ПМА, 2001-2002, д. Коровино); «Свадьбыто по-русски справляли» (ПМА, 2001-2002, д. Нижний Тымбай); «Свадьба у нас была по-русски, песни русские. С русскими мы [чуваши] быстро подружились» (ПМА, 2001-2002, д. Малые Кусты). 
Таким образом, иноэтническое окружение стало одной из причин слабой сохранности комплексов традиционной культуры чувашей Прикамья.

Как видно, в начале 1930-х гг. этническая культура чувашей Прикамья развивалась в условиях тесного взаимодействия с местной средой. Их этнокультурные комплексы адаптировались и к новым природно-климатическим и ландшафтным условиям, и к доминирующему иноэтническому, преимущественно русскому, окружению, обладающему своеобразием местных традиций. Отдельные комплексы духовной и материальной культуры (жилые и хозяйственные постройки, одежда, пища, обрядность, фольклор) по-разному трансформировались в новых условиях.

\section{ВЫВОДЫ}

Переселенческая кампания на территории Пермского Прикамья в 1928-1930 гг. не только привела к росту населения, но и сформировала локальные этнодисперсные группы чувашей, оторванные от мест традиционного проживания и оказавшиеся в иноэтнокультурном, преимущественно русском окружении. Проведенный анализ полевых материалов и письменных источников позволяет глубже взглянуть на особенности как переселенческой, так и в целом национальной политики СССР 1920-х - 1930-х гг. Процесс адаптации этих переселенцев не только был связан с обустройством на новом месте, но и привел к проблемам в отношениях с местным населениям, которое отнеслось к новым жителям настороженно. Отсутствие специальной работы в этом направлении спровоцировало ряд инцидентов.

Нельзя не отметить, что переселение в 1920-е гг. проходило в условиях характерного для всей страны разрушения традиционного уклада, смены идеологических установок, значительной трансформации этнокультурных комплексов. В условиях миграции эти факторы способствовали более интенсивному протеканию процессов «размывания» этнических традиций, их замене унифицированными элементами советской массовой культуры. Ещё одна специфика чувашей в Пермском Прикамье состояла в том, что они были выходцами из разных районов, носителями разных локальных традиций в языке, костюме и обрядности. В условиях совместного проживания происходило смешение и взаимодействие разных элементов локальных традиций. В то же время значительная численность чувашских переселенцев, расселение одним ареалом в отдалении от крупных населенных пунктов, сохранение сельского характера расселения способствовали обеспечению функционирования инсти- 
тутов сохранения традиционного уклада, их межпоколенческой трансляции.

\section{БЛАГОДАРНОСТИ}

Статья публикуется в рамках реализации гранта РНФ (проект № 19-18-00 117).

\section{Список литературы}

Архив Национально-культурного центра чувашей Пермского края (АНКЦЧПК). (2012). Письма семьи Яковлевых.

Баранов, М. Э. (1929). Переселение и коллективизащия. Москва: Книгосоюз.

Большаков, М. А. (1923). Задачи и перспективы колонизации. Земельное дело: Сборник статей по вопросам земельной и сельскохозяйственной политики, экономики, техники и организации земельного дела, колонизации и переселения и земельного дела за границей, (12), 125.

ВКП (б). Резолюция областного совещцания партработников нащмен (15-18 мая 1927 г.). (1927). Свердловск: Уралполиграф.

Всесоюзная перепись населения 1939 года: Уральский регион: Сборник материалов. (2002). Екатеринбург: Издательство гуманитарного университета.

Государственный архив Свердловской области. (1933). Ф. Р-88. On. 1. Д. 1610.

Государственный архив Свердловской области. (1934). Ф. P-88. Оп. 1. Д. 169.

История Чувашии новейшего времени: В 2 книгах. (2001). Чебоксары: Издательство ЧГИГН.

Каменских, М. С. (2018). Этносоциальные последствия переселенческой политики СССР на Урале в конце 1920-х годов. Вестник Пермского Научного Центра УРО РАH, (2), 61-67. doi: 10.7242/1998-2097/2018.2.9

Коровушкин, Д. Г. (2009). Чуваши в Западной Сибири: Расселение и численность в коние XIX - начале XXI века. Новосибирск: Издательство Института археологии и этнографии СО РАН.

Лебедев, Ф. (1925). Население Уралобласти. Хозяйство Урала, (5-6), 121-129.

Либкинд, А. С. (1931). Аграрное перенаселение и коллективизация деревни. Москва: Мосполиграф̆.

Лубны-Герцык, Л. И. (1923). Что такое перенаселение. Москва.

Пермский государственный архив социально-политической истории (ПермГАСПИ). (1937c). Ф. 643/2. On. 1. Д. 9543. Т. 2.

Пермский государственный архив социально-политической истории (ПермГАСПИ). (1937a). Ф. 643/2. On. 1. Д. 29512. 
Пермский государственный архив социально-политической истории (ПермГАСПИ). (1937b). Ф. 643/2. On. 1. Д. 33095.

Платунов, Н. И. (1976). Переселенческая политика Советского государства и её осуществление в СССР (1917-Июнь 1941 г2.). Томск: Издательство Томского университета.

Полевые материалы автора (ПМА). (2001, 2002). Куединский, Чайковский и Еловский район Пермской области.

Российский государственный архив экономики (РГАЭ). (1927). Ф. 5675. On. 1. Д. 2.

Федоров, Е. (1928). Переселение на Урал. Хозяйство Урала, (8-9), 6-33.

Центральный государственный архив Удмуртской Республики (ЦГА УР). (1929). Ф. P-370. On. 1. Д. 768.

Чепкасов, Л. И. (2010). Деревня моя Пантелеевка. Пермь.

Черных, А. В. (2001). Старообрядчество южных районов Пермской области в контексте этнокультурной истории. В Старообрядческий мир Волго-Камья. Проблемы комплексного изучения. Материаль научной конференции (сc. 133-158). Пермь.

Черных, А. В., \& Каменских, М. С. (2014). Чуваши в Пермском крае: Очерки истории и этнографии. Санкт-Петербург: Маматов.

\section{References}

All-Union Population Census of 1939: Ural Region: Proceedings. (2002). Yekaterinburg: Humanitarian University Press. (In Russian).

Archives of the National Cultural Center of the Chuvash People of Perm Region. (2012). Letters of the Yakovlev family. (In Russian).

Author's Field Materials. (2001, 2002). Kuedinsky, Chaikovsky, and Yelovsky districts of the Perm region. (In Russian).

Baranov, M. E. (1929). Resettlement and Collectivization. Moscow: Knigosoyuz. (In Russian).

Bolshakov, M. A. (1923). Tasks and Prospects of Colonization. Land Affair: A Collection of Articles on Land and Agricultural Policy, Economics, Technology and Organization of Land Affair, Colonization and Resettlement, and Land Affair Abroad, (12), 125. (In Russian).

Central State Archive of the Udmurt Republic. (1929). F. P-370. In. 1. C. 768. (In Russian).

Chepkasov, L. I. (2010). My village Panteleevka. Perm. (In Russian).

Chernykh, A. V. (2001). Old Believers in the Southern Districts of the Perm Region in the Context of Ethnocultural History. In The Old Believer world of the Volga-Kama region. Problems of complex study. Proceedings of the Research Conference (pp. 133-158). Perm. (In Russian).

Chernykh, A. V., \& Kamenskikh, M. S. (2014). Chuvashes in the Perm Territory: Essays on History and Ethnography. St. Petersburg: Mamatov. (In Russian). 
Fedorov, E. (1928). Resettlement to the Urals. Economy of the Urals, (8-9), 6-33. (In Russian).

History of Chuvashia in Recent Times: In Two Books. (2001). Cheboksary: Cheboksary State University Press. (In Russian).

Kamenskikh, M. S. (2018). Ethnosocial Consequences of the USSR Resettlement Policy in the Urals in the Late 1920s. Bulletin of the Perm Scientific Center URO RAS, (2), 61-67. doi: 10.7242/1998-2097/2018.2.9 (In Russian).

Korovushkin, D. G. (2009). The Chuvash in Western Siberia: Settlement and Numbers in the Late 19th and Early 21st Centuries. Novosibirsk: Publishing house of the Institute of Archaeology and Ethnography of the Siberian Branch of the Russian Academy of Sciences. (In Russian).

Lebedev, F. (1925). Population of the Urals region. The economy of the Urals, (5-6), 121-129. (In Russian).

Libkind, A. S. (1931). Agrarian overpopulation and collectivization of the village. Moscow: Mospoligraf. (In Russian).

Lubny-Gertsyk, L. I. (1923). What is overpopulation. Moscow. (In Russian).

Perm State Archives of Social and Political History. (1937a). F. 643/2. In. 1. C. 29512. (In Russian).

Perm State Archives of Social and Political History. (1937b). F. 643/2. In. 1. C. 33095. (In Russian).

Perm State Archives of Social and Political History. (1937c). F. 643/2. In. 1. C. 9543. T. 2. (In Russian).

Platunov, N. I. (1976). Resettlement Policy of the Soviet State and its Implementation in the USSR (1917 - June 1941). Tomsk: Tomsk University Press. (In Russian).

Russian State Archive of Economics. (1927). F. 5675. In. 1. C. 2. (In Russian).

State Archive of Sverdlovsk region. (1933). F. P-88. In. 1. C. 1610. (In Russian).

State Archive of Sverdlovsk region. (1934). F. P-88. In. 1. C. 169. (In Russian).

VKP (b). Resolution of the Regional Meeting of Party Workers of the Natsmen (May 15-18, 1927). (1927). Sverdlovsk: Uralpoligraf. (In Russian). 